\title{
Aba Festival as a Channel of Communication among the People of Etuno (Igarra), in Edo State, Nigeria.
}

\author{
Ezekiel S. Asemah, Angela N. Nwammuo, Leo O. N. Edegoh, \\ Department of Mass Communication, Kogi State University, Anyigba, Kogi State, Nigeria, \\ Ph.D, Department of Mass Commutation, Anambra State University, Uli, Anambra State, Nigeria. \\ Department of Mass Communication, Anambra State University, Igbariam Campus, Anambra State, Nigeria,
}

\begin{abstract}
This paper examines the Aba festival as a channel of communication among the people of Etuno in Akoko Edo Local Government Area of Edo State, Nigeria. The rationale behind the paper is to ascertain whether the Irepa festival, which is celebrated once in six (6) years in Etuno, Igarra, is a good means of communication among the people. The study is anchored on symbolic interaction theory and the coordinated management of meaning theory. Aba festival is a good means of passing cultural messages among the people of Etuno in Igarra, Edo state. Festivity is a means of communicating among the Etuno people and it is still important in the contemporary society. Indigenous media can be used to transmit cultures, values and norms of the rural dwellers from one generation to the other. The paper concludes that "Aba" festival is very significant in Etuno land, but it has not been known to people in other communities. The paper therefore recommends among others, that traditional communities should have value for festivity as a means of communication.
\end{abstract}

Key Words: Festivity, Indigenous Communication, Culture and Cultural Transmission.

\section{Introduction and Conceptual Clarification}

Communication is a means through which individuals exchange ideas, feelings, opinions, etc. This perhaps explains why Asemah (2011,p. 1) notes that communication is a phenomenon that can best be explained by the impact or the effect it causes. More so, Orewere (2006), cited in Asemah (2011:1) notes that human beings do not like to live alone, they love and desire to live in a place where there are other human beings, they interact with one another, in order to satisfy their wants, needs and goals. This interaction is initiated, promoted and achieved through communication. Communication is the process through which individuals or groups of individuals exchange ideas, information, messages, feelings and emotions, through previously agreed symbols, in order to influence each other. This also explains why MacBride $(198$, p.3) maintains that communication maintains and animates life and that it is also the motor and expression of social activity and civilisation, which leads people and peoples from instinct to inspiration, through variegated processes and systems of enquiring, command and control. This shows how relevant communication is in every society. It shows that no society can exist without communication.

Thus, Ndolo (2006) sees the indigenous media as credible an acceptable channels of communication utilised by rural dwellers for various functions, including dissemination of messages. The "Aba" festival that is celebrated among the "Igarras (Etuno)" in Akoko Edo Local Government Area of Edo State, Nigeria, is used to transmit cultures, values and norms of the people from one generation to the other. It is in line with this that the paper examines the "Aba" festival as a channel of communication among the Etunos (Igarras) in Akoko Edo Local Government Area of Edo State, Nigeria.

\section{What then is Communication?}

Communication is the process of exchanging ideas, feelings, messages, etc. between two or more people through previously agreed symbols or codes or language. Corroborating this definition, Idowu, in Mojaye, Arhagba, Soola and Oso (2008,p.769) says that communication is the process of transmitting mutually understandable and meaningful message that is, information between two or more interacting parties. The import of the definition is that communication is not just giving of information, it is the giving of understandable information and receiving and understanding the message. For communication to be effective, there must be a common understanding of the information by the parties involved.

According to Orewere (2006,p.3), the oldest meaning of communication in English can be summarised as the passing of ideas, information and attitudes, from person to person or from one to many other persons or people. Communication, apart from being essential, is also the central fact of human existence and social process. Nobody can be an Island without communicating with others in one way or the other and existence would be impossible without it. Wilson $(1993$, p.14) says communication is the process involving the sorting, 
selecting and sharing of symbols in such a way as to help a receiver elicit from his or her own mind, a meaning similar to that contained in the mind of the communicator.

\section{An Overview of Aba Festival}

The Aba festival is celebrated once in every six calendar years. The festival is made up of several ceremonies, which are not less than twenty five. For example, beating of Aba drums, Manhood Dance (Ututanebe), etc. The origin of the festival has been traced to Anafuas who were the aborigines of the present day Igarra. The Anafuas were said to be dwarfish, but diabolical race. The Anafuas were said to have posed a serious threat to the existence of the Igarra people, hence they later saw to it that the race was completely annihilated. It was said that before they were finally wiped out, they thought the Igarra people the secret of the Igarra festival, which has to do with the administration of the communities.

The festival has two faces; the traditional rites and the ceremonies. The traditional rites are inherent in the festival and serve as the core of such a festival while the ceremonies are outward, serving as a cloak. In the Irepa festival, the traditional rites are shared among the families. There is no family or person that has overall authority on the traditional rites of the festival. However, the ceremonies are enjoyed by all the people. The traditional rites and the beating of the Aba drums, which is the climax of the ceremonies, are best known to the Ezia-Kuta family. The drums are usually beaten in August of every "Aba" festival period to herald the beginning of the festival. The traditional rites is the beginning of the festival. The traditional rites is done in the beginning of the second Aba drums (Ofuofifu), in January of every "Aba" festival or period at Ugbogbo; it is controlled by the Anona family. The Anoseri, Eghimozoko and the Eghinagada families control the traditional rites of beating the Arido drums. The traditional rites is the beating of the last Aba drums (Okukuku), in the last ceremony before taking of elders titles (AZEGBANI) is controlled by the Anonyete Family. The ceremonies flow into one another without hindrance from the start to the end (Ometere Age group presentation).

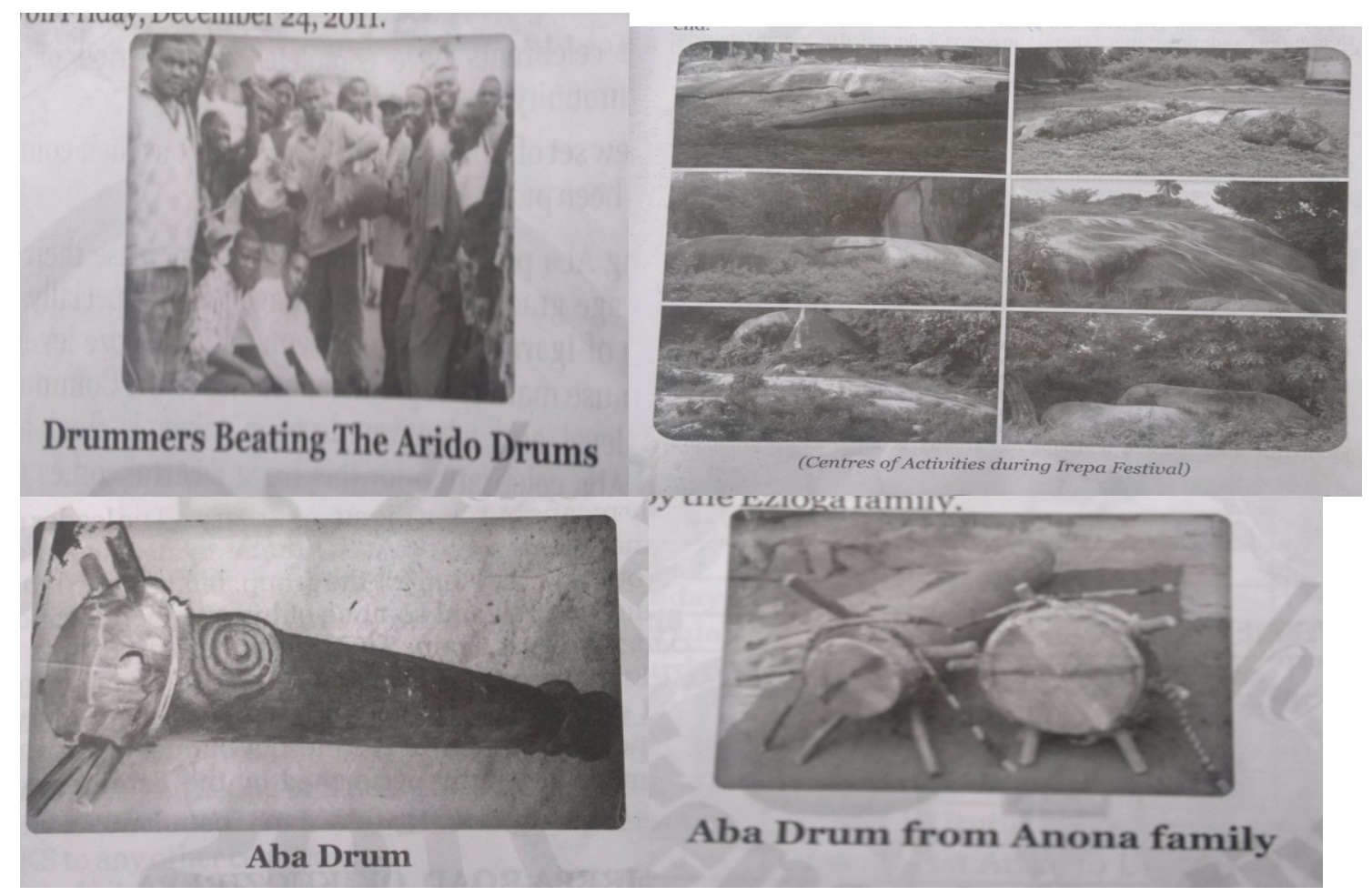

\section{Theoretical Background}

For us to have a better understanding of this paper, two theories have been chosen. They are symbolic interaction theory and coordinated management of meaning theory. The symbolic interaction theory was propounded by Herbert Miller in 1993. This theory suggests that people are motivated to act, based on the meanings they assign to people, things and events. Meaning is created in the language that people use both with others and in private thought. Language allows people to develop a sense of self and to interact with others in community. Symbolic interaction comes from the socio-cultural perspective in that it relies on the creation of shared meanings through interactions with others. Going by the theory, the world is made up of social objects that are named and have socially determined meanings. When people interact overtime, they come to a shared meaning for certain terms and actions and thus, come to understand events in particular ways. 
This perhaps explains why Folarin (1998) notes that the symbolic interaction theory is predicated on the presence of a socialiser and a socialisee, both affecting and being affected by the work situation in which, interactions develop the socialisee and reinforces the values of the socialiser. Baran, cited in Yaroson and Asemah (2008) notes that the theory was borrowed from the psychologists. It assumes that cultural symbols are learned through interactions and then, mediate those interactions. One of the major assumptions of the symbolic interaction theory, according to Anaeto, Onabajo and Osifeso (2008) is that communication occurs through the creation of shared significant symbols.

The theory is relevant to the study; it is a wide ranging theory that links language with perception, thinking, self concept and culture. Thus, when human beings are deprived of communication, they may not be able to function effectively. This is because, in the traditional setting, we are more engaged in interpersonal communication.

Coordinated management of meaning theory proposes that in conversation, people co-create meaning by attaining some coherence and coordination. Coherence occurs when stories are told and coordination exists when stories are lived. Through a hierarchical structure, individuals come to organise the meaning of literally hundreds of messages received throughout a day. This theory simply assumes that two individuals engaging in an interaction are each, constructing their own interpretation and perception behind what a conversation means. A core assumption within this theory includes the belief that all individuals interact, based on rules that are expected to be followed while engaging in communication.

The relevance of the theory to the study cannot be overemphasised; the theory proposes that when we coordinate and manage meaning, we want to get meaning from what has been communicated. Thus, through communication, people communicate reality. Through communication, we are able to create ideas and realities. The theory suggests that all of us use communication to coordinate our actions with behaviours of others. Since it is through interpersonal communication, there are certain things in life that are not yet known, but through communication, you make such things known. Through the "Aba" festival, the Etuno people in Akoko Edo Local Government Area of Edo State, Nigeria, can make their culture known to the entire world.

\section{Area of Study}

The study is restricted to the examination of Aba festival as a channel of communication among the Igarra (Etuno) people of Edo State, Nigeria. Geographically, the area of study is Igarra (Etuno) in Akoko Edo Local Government Area of Edo State, Nigeria. Igarra is a town located in the Northern outskirts of Edo state, Nigeria; a place very peaceful and unique for her customs and traditions. It is the administrative headquarters of the Akoko Local Government Area of Edo State. The distance from Benin City, Edo state capital, to Igarra is about 160 kilometers. Its topography is mountainous and situated on the lee-wind side of the Kukuruku Hill, with rocky terrain. Igarra has both Christians and Muslims and traditional festivals are always celebrated (Ogumah, 2011).

Igarra people migrated from the Kwararafa confederacy of the Junkun kingdom of Wukari in the present Taraba state of Nigeria in about the $21^{\text {st }}$ century to Idah, in the present Kogi state. They lately migrated from Idah about the year 1400. They were led by Ariwo Ovejijoh, who is said to be a disappointed claimant to the post of Atta of Igala land, having co-inhibited with the Igala/Okpoto union with his followers, for over three centuries. After Idah, Ariwo Ovejijoh and his followers were said to have stayed briefly at Ajaokuta before migrating west wards from there to the present place called Etuno. However, some of his followers remained at Ajaokuta settlement, but lately came to Igarra Etuno as families to join their Kit and kin.

When Igarra people migrated to this present place originally known as Etuno, they met a group of people called ANAFUA, ANIVA and ANDAKONI. They were headed by a man known as 'UNO', these people were the aborigines of Etuno kindred. Most of them were later exterminated by Igarra people warfare while the remaining few ones fused into some kindred and pledged their loyalty to the Igarra king. Etuno means the land of "UNO" it is a derivative name from the said leader of the aborigines "UNO". Ete means land in Igarra dialect while UNO was the name of the leader of the first occupiers of aborigines of Etuno land. It is a common practice that a place is named from a physical feature or after a person as first occupier, settler or the leadership in the place. The Igarra people settled first at the root of the Kukuruku Hills, but later moved to the ridge and caves of the hills, because of intertribal war. Some of the people moved down to the present site in 1911 and the remainder in 1917, when the intertribal wars were ended.

\section{Understanding Indigenous Channels of Communication}

Communication has been described as the process of exchanging ideas between two or more groups of people. Communication takes different forms, intra, interpersonal, group, international, cultural, religious, indigenous, etc. This explains why Ndolo (2006) observes that:

Before the advent of the modern mass media (radio, newspaper, magazines and television), people were able to disseminate information through indigenous means; Every society's growth, survival and continuity depends on 
among other things, a system of communication through which people could exchange ideas and feelings; an economic system, the production of goods and services, a health system to counteract diseases and ensure human reproduction; a socio-political system to maintain and control and order and a deference system to protect their territories against external aggression.

Ndolo's assertion shows that communication has been in existence, right from time immemorial. Wilson (1997) observes that the traditional media describe the indigenous modes of communication in Africa. It is the multi-channel system, which is employed in most rural areas (villages, clans, towns, wards, herds), as well as, in rural/urban setting. Wilson further maintains that traditional media are an admixture of social conventions and practices, which have become sharpened and blended into veritable communication modes and systems and which have almost become standard practices for societies.

Asemah (2011) notes that indigenous communication media can be used to transmit cultures, values, norms, etc, from one generation to the other. Thus, they socialise few members of the society and also tell them about the secrets of the society. They teach the rural dwellers their culture and norms. This focuses on the communication of knowledge, values and social norms, from one generation to another, from members of a group to new comers. There are different means of indigenous communication. Asemah (2011) identifies the indigenous means as:

i. Masquerade: This is one of the traditional media that is still used by most rural dwellers in Africa today. The coming out of masquerade connotes different things in different societies. In Igarra, Edo state for example, masquerade is used to honour the oldest person who dies.

ii. Gunshots: Gunshots are used to communicate during festive periods. In Igarra, Edo state, the celebrations of the "Abba Festival" is accompanied with gunshots. It is a festival that is celebrated once in 7 years.

iii. The Town Crier: The voice of the town crier or village gongman is usually heard in the early hours of the morning, preceded by the sound of a gong. He announces important meetings, ceremonies, messages and imminent troubles. Ugoboajah (1985) sees the town crier as a significant village broadcaster who summons the elders for decision- making and relays their decisions to the village masses for implementation. Always loaded with news, the village gongman serves as the traditional communication link between the legal head and the villagers. His effectiveness usually lies in his oratory skills and thorough knowledge of the community norms, values and heritages.

The town crier or village announcer is the community announcer who goes round the community hitting a bell or a gong to draw attention. The town crier often stands at a vantage position to announce what he has for the people. Among the Hausas, he is the "Mai Shela"; usually selected by the Sarki or Village Head, but revered as a holy man whose announcements are never doubted. One of his major duties is the announcement of the date and time for the new moon, which signifies the beginning of the Ramadan festivals. Among the Yorubas, he is the "gbohun- gbohun" whose duty among others, includes announcement of the celebration days for the Sango Religious Festivals. Among the other various ethnic groups in Nigeria, he occupies no less credible and authoritative position (Ndolo, 2006).

iv. The Talking Drum: The talking drum is an extension of oral tradition and can vary from membranophones, like the hour- glass -shaped drum of the Yorubas, to the large tomtoms or silt drum "ekwe" of the Igbos. Talking drums reproduce the tonal pattern of a sentence in the proper sequence and can be heard over a long distance. Their community functions are two-pronged: official and social. Officially, they are used to call meetings, for making some official announcements, at sacrificial ceremonies and for pumping the adrenaline during wars. Socially, they provide gaiety during festivities and ceremonies like new-yam festivals, weddings and chieftaincy titles, and they provide the atmosphere of suspense and tension during wrestling matches. In Nigeria today, drummers can be seen at almost every social and even funeral events soliciting for money by singing the praise of wealthy and highly placed members of the society.

v. Age Group: Age groups are old institutions that comprise mostly males within the same age-brackets; usually those born within one to five age ranges.

vi. Smoke Signals: Smoke signals are almost none existent in modern Nigeria. It is one of the earliest communication patterns between distant communities. They were used to exchange information based on agreed codes.

vii. Objectifics: Media presented in concrete forms which may have significance for a specific society only or may have universal meaning through their traditional association with specific contextual meanings. These include kola nut, charcoal, white pigeon or fowl, white egg, feather, cowries, mimosas, flowers, sculpture, pictures drawings and the flag.

viii. Music: Songs convey meanings that relate to the cultural norms and values of the people. The songs can be used to warn, entertain or to simply inform. Itinerant musical entertainment groups sing all kinds of songs- praise songs and generally criticise wrong doings of individuals in the society. Names of those beings 
satirised or praised may be mentioned or descriptions of their physical or personality attributes given; where they live or what they do may form part of such songs. Grapevine stories concerning events that are being planned for the society may be features as a way of alerting the generality of the people. Such groups are potent sources of information.

ix. Extra-Mundane Communication: This is the mode of communication between the living and the dead, the supernatural or Supreme Being. It is usually done through incantation, invocation, spiritual crafts, rituals, prayers, sacrifices, trances, hysterics and liberation. It is a multi-dimensional communication transaction which has become pervasive in all societies, most especially in Africa. Cultural/ritual performance evokes intensity of emotions, which may lead to a temporary trans-migration of participants as in religious or spiritual ceremonies. Such performances convey the elements of a cultural celebration, dedication and consecration as it is often witnessed in marriage and funeral rites. Modern forms of extra-mundane communication are found in obituary and in memorial notices published in newspapers, magazines or radio.

\section{Discussion}

Aba festival is a channel through which the Etuno people showcase their culture to the entire world. Culture is the learned behaviour of members of a given social group. It is the learned, socially acquired traditions and lifestyles of the members of a society, including their patterned, repetitive ways of thinking, feeling and acting. Taylor (1991) sees culture as that complex whole, which include knowledge, beliefs, art, morals, laws, customs and any other capabilities acquired by man, as a member of the society. Culture can be seen as the whole way of life of a people, which include their customs, habits, beliefs, religions and crafts, language, technology, dance, etc. It includes the rules and regulations that govern the behaviours of people in a given society. Society is known by its culture.

The concept of culture is the specific system of norms, beliefs, practices, techniques and objectives that the people of a given society have inherited from their fore-fathers, have invented or have adopted from other sources. Culture is all that man has added to nature. According to Gertz, cited in Taylor (1991), culture is a historically transmitted pattern of meaning embodied in symbolic forms by means of which people communicate, perpetuate and develop their knowledge about and attitudes towards life. Thus, the "Aba" festival is a channel of transmitting and preserving the culture of the Etuno people of Akoko Edo Local Government Area of Edo State. A people without culture will not be able to stand the text of time in society, as the people will not be known. Thus, the "Aba" festival is celebrated to reveal the cultural of Etunos as a people, thus, during the celebration, people (celebrants) appear in white.

More so, "Aba" festival is celebrated to commemorate the defeat of the original settlers, (ANAFUAS, THE DWARF). The site where celebrate the festival, is called OFUAMOMO SITE, along Oshomorika road, Igarra. The festival is celebrated among the Etuno people as a means of transiting from one age group to another. This is because it is used to know the end of age group, as people transit from one age group to another. And it is done by the age group called AZEBANI, meaning the BIG MEN.

\section{Summary and Conclusion}

Indigenous media can be used to transmit cultures, values and norms of the people from one generation to the other. The paper concludes that "Aba" festival is very significant in Etuno land, but it has not been known to people in other communities. Based on the conclusion arrived at in this study, the paper recommends that the Etuno people should endeavour to make the "'Aba" festival known across Nigeria, and if possible, across the globe. This can be done by using the mass media to showcase the festival, traditional communities should have value for festivity as a means of communication.

\section{References}

[1]. Ailoje, J (2002) Aspects in politics and administration. Akure: Sylva Publishing Incorporate.

[2]. Anaeto, S., Onabajo, O and Osifeso, J. (2008). Models and theories of mass communication. Renaissance Book Incoiporated.

[3]. Asemah, E.S. (2011). Perspectives on advertising and public relations. Jos: Lizbon Press.

[4]. Asemah, E.S. (2011). Selected mass media themes. Jos: University Press.

[5]. Baran, S. (2002). Introduction to mass communication, media literacy and culture $\left(2^{\text {nd }}\right.$ ed). New York: McGraw Hill Higher Education.

[6]. Folarin, B. (1998). Theories of mass communication: An introductory text. Ibadan: Stirling- Horden Publishers.

[7]. Idowu, O. (2008). Dialogue as an essential instrument in conflict resolution and management. In E, Mojaye., E, Arhagba., E, Soola and L, Oso. (eds). Dialogue, peace building and reconciliation: Conference proceedings. Abraka: ACCE.

[8]. Irepa Festival Celebration: A Celebration of Ometere Age Group. The 37th Opoze of Igarra,

[9]. MacBride, S. (1980). Many voices, one world. New York: UNESCO Press.

[10]. Ndolo, I .(2006). Mass media system and society. Enugu: Rhyce Kerex Publishers.

[11]. Ogumah, A.U .(201 1). The Igarra traditional rulership: Facts and fiction. Benin: Neat Prints.

[12]. Orewere, B .(2006). The mass communicator and the audience. Jos: Karix Production. 
[13]. Ugboaja, F. (1985). Ora media in Africa. In F, Ugboaja. (Ed). Mass communication, culture and society in West Africa. Munchem: Hanszell.

[14]. Wilson, S. (1993) Mass media and mass culture: An introduction. New York: Prentice Hall Publishers.

[15]. Wilson, D. (1997). Communication and aocial action. Port Harcourt: Foot Step Publication.

[16]. Yaroson, E.D and Asemah, E.S. (2008). Theories and models of mass communication. Jos: Great Future Printing and Business Centre. 